\title{
Introduction to the Special Issue on Stem Cells and Regenerative Medicine
}

\author{
Qinan Yin \\ Clinical center, National Institutes of Health, Bethesda, MD, USA
}

The special issue "Stem Cells and Regenerative Medicine" was enthusiastically released by the Editorial Board of European Journal of Histochemistry on 2020. The fusion of these two topics reflected the hope and potential that advances in regenerative medicine would be the promising outcomes of the basic and translational research collected in this special issue. This issue is dedicated to identifying priories in stem cell biology and capturing the cutting-edge thinking in stem-cell based regenerative medicine.

Stem cells are identified as undifferentiated cells capable of self-renewal, differentiation into different types of cells, proliferation and regeneration of tissues. Since 1960s, following the first identification of hematopoietic stem cells (HSCs) by McCulloch and Till, ${ }^{1}$ mesenchymal stem cells (MSCs) were subsequently isolated by Friedenstein and his colleagues from bone marrow in $1976 .^{2}$ In 1981, Lotfinegad and colleagues ${ }^{3}$ isolated the first embryonic stem cells (ESCs) from the inner cell mass (ICM) of mouse and since then, ESCs have been isolated from other mammals such as sheep, ${ }^{4}$ rabbits, ${ }^{5}$ cattle ${ }^{6}$ and human. ${ }^{7}$ About 25 years later, the discovery of induced pluripotent stem cells (iPSCs) by Shinya Yamanaka ${ }^{8}$ was heralded as a major breakthrough of the decade in stem cell research. Along with new fundamental discoveries in stem cells, the field of stem cell biology has sparked scientists' interest to the point that stem cells, capable of growing indefinitely in vitro and maintaining the capacity of differentiation, could work as "model" organisms to study organogenesis and the therapeutic potential of transformative regeneration.

Promising results from preclinical studies and clinical trials deepen our appreciation of application of stem cells in regenerative medicine. Stem cell-based therapy applies the understanding of stem cell development, differentiation, and maintenance to generate new, healthy tissue for diseases needing transplant or replacement of damaged tissue, such as heart failure, ${ }^{9}$ cirrhosis, ${ }^{10}$ diabetes mellitus, ${ }^{11}$ leukemia, ${ }^{12}$ Crohn's disease, ${ }^{13}$ neurodegenerative disease ${ }^{14}$ and so on. However, widespread implementation of stem cells in regenerative therapeutics remains a big challenge. Either ESCs or iPSCs has a risk of tumor formation after injection into the host. ${ }^{15}$ On the other hand, genetic and epigenetic instabilities of stem cells during reprogramming may cause cellular impairment, organismal aging and even malignant outgrowth $^{16}$ and thus set severe limitations in clinical applications. Finally, stem cell-based therapy is also ethnically challenging. We should consider the integration of existing ethical frameworks with new ethical implications to move forward this field.

Aside from casting a spotlight on stem cell biology and its regenerative application, the launch of this special issue will also explore different immunohistochemical methods used in characterizations of stem cells. This field is clearly of particular interest to European Journal of Histochemistry. All the stem cell-related papers published in the journal will be collected together in this issue, providing a one-stop shop for stem cell researchers to find the ideal approaches.

Stem cell in regenerative medicine is an area of biomedical sciences where several exciting discoveries may be disseminated prior to full peer review and publication. We hope that this timely collections of papers from excellent scientific researchers may contribute greatly to this field, through the introduction of stem cell history and recognition of the common challenges that lay ahead in a well-balanced manner. Clearly, the field has a responsibility to communicate openly and fairly about advances, as well as failures, so that the audience could benefit maximally from European Journal of Histochemistry.

Correspondence: Qinan Yin, Clinical center, National Institutes of Health, Bethesda, MD, USA.

E-mail: qinan.yin@nih.gov 


\section{References}

1. Till JE, Mc CE. A direct measurement of the radiation sensitivity of normal mouse bone marrow cells. Radiat Res 1961;14:213-22.

2. Friedenstein AJ. Precursor cells of mechanocytes. Int Rev Cytol 1976;47:327-59.

3. Lotfinegad P, Shamsasenjan K, Movassaghpour A, Majidi J, Baradaran B. Immunomodulatory nature and site specific affinity of mesenchymal stem cells: a hope in cell therapy. Adv Pharm Bull 2014;4:5-13.

4. Handyside A, Hooper ML, Kaufman MH, Wilmut I. Towards the isolation of embryonal stem cell lines from the sheep. Roux Arch Dev Biol 1987;196:185-90.

5. Giles JR, Yang X, Mark W, Foote RH. Pluripotency of cultured rabbit inner cell mass cells detected by isozyme analysis and eye pigmentation of fetuses following injection into blastocysts or morulae. Mol Reprod Dev 1993;36:130-8.

6. Cherny RA, Stokes TM, Merei J, Lom L, Brandon MR, Williams RL. Strategies for the isolation and characterization of bovine embryonic stem cells. Reprod Fertil Dev 1994;6 569-75.

7. Thomson JA, Itskovitz-Eldor J, Shapiro SS, Waknitz MA, Swiergiel JJ, Marshall VS, Jones JM. Embryonic stem cell lines derived from human blastocysts. Science 1998;282:1145-7.

8. Takahashi K, Yamanaka S. Induction of pluripotent stem cells from mouse embryonic and adult fibroblast cultures by defined factors. Cell 2006;126:663-76.
9. Nguyen PK, Rhee JW, Wu JC. Adult Stem cell therapy and heart failure, 2000 to 2016: A systematic review. JAMA Cardiol 2016;1:831-41.

10. Kuo TK, Hung SP, Chuang CH, Chen CT, Shih YR, Fang SC, et al. Stem cell therapy for liver disease: parameters governing the success of using bone marrow mesenchymal stem cells. Gastroenterology 2008;134:2111-21, 2121.e1-3.

11. Kroon E, Martinson LA, Kadoya K, Bang AG, Kelly OG, Eliazer S, et al. Pancreatic endoderm derived from human embryonic stem cells generates glucose-responsive insulinsecreting cells in vivo. Nat Biotechnol 2008;26:443-52.

12. Gratwohl A, Heim D. Current role of stem cell transplantation in chronic myeloid leukaemia. Best Pract Res Clin Haematol 2009;22:431-43.

13. Oyama Y, Craig RM, Traynor AE, Quigley K, Statkute L, Halverson A, et al. Autologous hematopoietic stem cell transplantation in patients with refractory Crohn's disease. Gastroenterology 2005;128:552-63.

14. Liu SP, Fu RH, Huang SJ, Huang YC, Chen SY, Chang CH, et al. Stem cell applications in regenerative medicine for neurological disorders. Cell Transplant 2013;22:631-7.

15. Huang CY, Liu CL, Ting CY, Chiu YT, Cheng YC, Nicholson MW, Hsieh PCH. Human iPSC banking: barriers and opportunities. J Biomed Sci 2019;26:87.

16. Kustikova O, Fehse B, Modlich U, Yang M, Dullmann J, Kamino K, et al. Clonal dominance of hematopoietic stem cells triggered by retroviral gene marking. Science 2005;308:1171-4.

This work is licensed under a Creative Commons Attribution-NonCommercial 4.0 International License (CC BY-NC 4.0)

(C) Copyright: the Author(s), 2020

Licensee PAGEPress, Italy

European Journal of Histochemistry 2020; 64(s2):3152

doi:10.4081/ejh.2020.3152 